\title{
Susceptible gene polymorphism in patients with three-vessel coronary artery disease
}

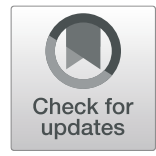

Ru Liu, Lei Song ${ }^{*}$, Lin Jiang, Xiaofang Tang, Lianjun Xu, Zhan Gao, Xueyan Zhao, Jingjing Xu, Runlin Gao and Jinqing Yuan ${ }^{*}$

\begin{abstract}
Background: Data of susceptible gene polymorphisms related to progression of coronary atherosclerosis in patients with three-vessel disease (TVD) is limited in China. This case-control study aimed to analyze the differences of variant carrier frequencies between cases and controls, and to explain the possible genetic effects on the progression of TVD.

Methods: A total of 8943 TVD patients were consecutively enrolled. Major adverse cardiac and cerebrovascular events (MACCE) included all-cause death, acute myocardial infarction, repeat revascularization, readmission and stroke. Patients with 1-year MACCE in this cohort were selected as MACCE group. Blood samples from MACCE group and non-CAD control groups were collected, and a deoxyribonucleic acid library was created. A total of 34 tag or hot single nucleotide polymorphisms (SNPS) in six genes including CDKN2B-AS1, ADAMTS7, ABO, ADAMTS13, IL-18, and PECAM1 were analyzed by a SNPscan ${ }^{\mathrm{TM}}$ multi-genotyping kit. Carrier frequencies of each SNP were compared between the two groups using dominant, recessive and codominant allele model, respectively. Multivariate logistic regression model was established.

Results: Variant allele frequencies of rs10757274, rs1333042, rs1333049, rs4977574, rs9632884, rs1063192 and rs3217986 on CDKN2B-AS1 gene showed significant differences between the two groups in at least one allele model. Variant allele frequency of rs3217986 was not statistically significant after adjusting for the false discovery rate using Benjamini-Hochberg procedure $(Q>0.05)$. Variant allele frequencies of rs1333049, rs 10757274, rs4977574 on CDKN2B-AS1 gene were significantly higher in MACCE group in all dominant, recessive and codominant models. Rs1055432 on ADAMTS13 and rs8176694 on ABO gene showed threshold significance between the two groups. After multivariable adjustment, G mutant homozygous rs9632884 (GG vs. GC + CC) (OR: 0.24; $95 \%$ Cl: 0.09-0.65; $P=0.005)$ on CDKN2B-AS1 gene were independent protective factor of MACCE in recessive model.
\end{abstract}

Conclusions: In patients with TVD in China, variant alleles on CDKN2B-AS1 gene may form part of the genetic basis of coronary atherosclerosis progression, promoting or suppressing ischemic events.

Keywords: Dominant model, Codominant model, Coronary artery disease, Recessive model, Single nucleotide polymorphism, Three-vessel disease

\footnotetext{
*Correspondence: songlqd@126.com; dr_jinqingyuan@sina.com Department of Cardiology, Fuwai Hospital, Chinese Academy of Medical Sciences, No. 167 North Lishi Road, Xicheng District, Beijing 100037, China
}

(c) The Author(s). 2020 Open Access This article is licensed under a Creative Commons Attribution 4.0 International License, which permits use, sharing, adaptation, distribution and reproduction in any medium or format, as long as you give appropriate credit to the original author(s) and the source, provide a link to the Creative Commons licence, and indicate if changes were made. The images or other third party material in this article are included in the article's Creative Commons licence, unless indicated otherwise in a credit line to the material. If material is not included in the article's Creative Commons licence and your intended use is not permitted by statutory regulation or exceeds the permitted use, you will need to obtain permission directly from the copyright holder. To view a copy of this licence, visit http://creativecommons.org/licenses/by/4.0/ The Creative Commons Public Domain Dedication waiver (http://creativecommons.org/publicdomain/zero/1.0/) applies to the data made available in this article, unless otherwise stated in a credit line to the data. 


\section{Background}

Coronary artery disease (CAD) is generated by multifactors including both genetic and traditional risk factors [1-12]. Acknowledged risk factors for CAD include age, male gender, family history of premature coronary artery disease, diabetes mellitus (DM), hypertension, dyslipidemia, obesity, cigarettes smoking, drinking and physical inactivity [13]. However, individual variation in the severity of lesions and long-term prognosis has been observed. Patients with similar lesions and receiving similar treatment may become stable or progress. On the contrary, a small proportion of CAD patients lack classical risk factors. Therefore, researchers think that genetic factors not only contribute to the occurrence of atherosclerosis but also to the progression of atherosclerosis, along with classical risk factors [14-16]. Data of susceptible gene polymorphisms related to the progression of coronary atherosclerosis in Chinese population is still limited [7, 8]. Therefore, we conducted this study to examine several susceptible gene polymorphisms in a group of patients with three-vessel disease (TVD), a severe type of $C A D$, who suffered from progression of coronary atherosclerosis, presented as 1-year adverse cardiac and cerebrovascular events during long-term follow-up. We analyzed the differences of variant allele frequencies between this "rapidly worsening" group of patients and non-CAD controls to explain the possible genetic effects on progression of TVD.

\section{Methods}

\section{Ethical statement}

Ethical approvals were obtained from the Fuwai Hospital Research Ethics Committees. The Institutional Review Board approved the study protocol and all patients signed written informed consent before the intervention, including full set of risk-informed consent and information use consent for scientific purposes.

\section{A TVD cohort with long-term follow-up}

A total of 8943 consecutive cases diagnosed as TVD by coronary angiography were prospectively enrolled from April 2004 to February 2011 in Fuwai hospital, Chinese Academy of Medical Sciences (Beijing, China). TVD was defined as angiographic stenosis of $\geq 50 \%$ in all three main epicardial coronary arteries, including left anterior descending, circumflex and right coronary artery, with or without left main artery involved. There were no exclusion criteria. Patients received optimizing drug therapy (ODT) alone, percutaneous coronary intervention (PCI) or coronary artery bypass grafting (CABG) according to contemporary practice guidelines and their preferences. Patients who received PCI or CABG were also treated with ODT according to guidelines. Clinical baseline and procedural data of all participants were collected into a database by independent clinical research coordinators. Follow-up pattern included telephone interview, follow-up letter and clinic visit. The last follow-up was finished in 2016, with the response rate of $80.6 \%$. All events defined by study protocol were carefully verified by an independent group of clinical physicians [17].

\section{Definitions and study population}

Major adverse cardiac and cerebrovascular events (MACCE) included all-cause death, acute myocardial infarction (AMI), stroke, repeat revascularization and readmission. Readmission only referred to ischemia-driven readmission and did not include elective readmission for complete revascularization. A total of 512 patients who suffered from1-year MACCE were selected as MACCE group, considered as rapidly worsening atherosclerotic cases. Because part of samples did not pass the deoxyribonucleic acid (DNA) quality test due to repeated freeze-thaw or experimental exhaustion, 342 cases were finally analyzed in MACCE group.

\section{Control group}

Non-CAD control group was enrolled with almost 1:1 ratio. Inclusion criteria including age $\geq 40$ years, no CAD history, no manifestation of myocardial ischemia or infarction on electrocardiogram, no regional wall motion abnormalities, wall thinning, ventricular enlargement or lowered ejection fraction on echocardiography, or coronary stenosis $<50 \%$ observed on multi-slice spiral CT coronary angiography or coronary angiography.

\section{DNA database and SNP genotyping}

Blood samples of MACCE and control groups were collected after enrollment at hospital admission. A blood sample database was created for DNA extraction. $\mathrm{Hu}$ man genomic DNA was extracted using a standard method as described by Chi S. et al. [18]. Single nucleotide polymorphism (SNP) genotyping was performed using a custom design 48-Plex SNPscan ${ }^{\text {тм }}$ Kit (Cat\#: G0104; Genesky Biotechnologies Inc., Shanghai, China). The assay was based on double ligation and multiplex fluorescence polymerase chain reaction (PCR). For the sake of clarity, a brief description of the genotyping protocol is included. 100-200 ng of DNA sample was denatured at $98^{\circ} \mathrm{C}$ for $5 \mathrm{~min}$ in a $10-\mathrm{ml}$ reaction containing $1 \times$ DNA lysis buffer and then mixed well with a 10 -ml ligation solution composed of $2 \mathrm{ml}$ of 103 ligase buffer, $0.5 \mathrm{ml}$ of ligase, $1 \mathrm{ml}$ of probe mix, and $7.5 \mathrm{ml}$ of Milli-Q water. The ligation reaction was carried out in an ABI2720 thermal cycler. Two 48-plex fluorescence PCR reactions were performed for each ligation product. PCR reactions were prepared in $20 \mathrm{ml}$ of a mixture containing $1 \times$ PCR master mix, $1 \mathrm{ml}$ of primer mix set $\mathrm{A}$ or 
set $\mathrm{B}$, and $1 \mathrm{ml}$ of ligation product. PCR products were separated and detected by capillary electrophoresis in an ABI3730XL sequencer. Raw data were analyzed according to information obtained for the labeling dye color and fragment size of the allele-specific ligation-PCR product. Subject's case or control status was blinded during genotyping. For quality control, repeated analyses were performed to ensure the reproducibility of the results by randomly choosing $4 \%$ of samples with high DNA quality.

\section{Candidate genes}

Overall, 34 tag or hot SNPs on CDKN2B-AS1, $A B O$, ADAMTS7, ADAMTS13, IL-18, and PECAM1 genes were selected as candidate SNPs. Relevant data of SNPs referred to genome wide association studies (GWAS) in the Han population. Data of susceptible genes of CAD referred to the HapMap database (Data Rel 27 Phase II + III, Feb09, on NCBI B36 assembly, dbSNP b126). Minor allele frequency (MAF) was $\geq 0.05, r^{2}>0.8$. An online software (http:// hapmap.ncbi.nlm.nih.gov/cgi-perl/gbrowse/hapmap27_ B36/\#search) was used for tag SNP selection. Thirtyfour candidate SNPs were rs974336, rs3217986, rs1063192, rs3217992, rs9632884, rs10757274, rs1333042, rs1333049 and rs4977574 on CDKN2B-AS1 gene (9p21.3); rs3743057, rs4887112, rs922693, rs11072806 and rs3825807 on ADAMTS7 gene; rs8176747, rs643434, rs8176668, rs500499, rs8176731, rs2073824, rs8176694, rs8176740 and rs8176707 on $A B O$ gene; rs3780809, rs1055432, rs671410, rs652600 and rs4962153 on ADAMTS13 gene; rs549908, rs5744280 and rs360722 on $I L-18$ gene; rs668 (rs281865545), rs12953 and rs1131012 on PECAM1 gene.

\section{Statistical analysis}

Data statistics was applied using SPSS 22.0 (IBM Corp., Armonk, New York, USA). Student's t-tests were used to compare continuous variables while Chi-square tests were applied to compare categorical variables between the two groups. SNP association analysis was applied in three allele models, dominant, recessive and codominant model, using Chi-square tests to compare variant allele frequency of each SNP between the two groups. Multivariate logistic regression analysis was conducted to evaluate the association between variant allele frequencies and adverse outcome. The results were reported as odds ratios (ORs) with 95\% confidence intervals (95\% CIs). Variables included in the multivariable model were those showed significant differences between the two groups in univariate analysis $(P<0.05)$. All analyses were two-sided, and statistical significance was defined as $P<0.05$. Tendency of significant difference was judged when $0.05<P<0.1$.

\section{Results}

Baseline data

Compared with control group, patients in MACCE group were presented with older age, more male, more comorbidities, higher inflammation markers (white blood cell count and high-sensitivity C-reactive protein level), lower hemoglobin, higher alanine transaminase and serum creatinine, higher fasting blood sugar level, lower high-density lipoprotein cholesterol level and lowdensity lipoprotein cholesterol level (Table 1).

\section{Candidate SNP association analysis}

Of all 34 SNPs on six candidate genes, variant allele frequencies of seven SNPs on CDKN2B-AS1 showed significant differences between MACCE group and control group in at least one kind of allele model. They were rs1063192, rs10757274, rs1333042, rs1333049, rs3217986, rs4977574 and rs9632884. Among them, variant allele frequencies of rs10757274, rs1333049 and rs4977574 were significantly different between the two groups in all three allele models. P-values of six SNPs still had statistical significance after adjusting for the false discovery rate (FDR) using Benjamini-Hochberg $(\mathrm{BH})$ procedure $(Q<0.05)$. G mutant of rs3217986 was not statistically significant after FDR BH adjustment $(Q>0.05)$. Variant allele frequencies of two SNPs showed tendency of significance: rs1055432 on ADAMTS13 gene and rs8176694 on $A B O$ gene $(0.05<$ $P<0.1)$. Variant allele frequencies of other SNPs showed no significant difference between the two groups in three models (all $P>0.05$ ) (Tables 2, 3).

\section{Multivariate logistic regression analysis}

In recessive model, $\mathrm{G}$ mutant homozygous of rs9632884 (GG vs. $\mathrm{GC}+\mathrm{CC})(\mathrm{OR}: 0.24 ; 95 \% C I: 0.09-0.65 ; P=$ $0.005)$ on $C D K N 2 B-A S 1$ was independently associated with decreased risk of MACCE in multivariate logistic regression model. $\mathrm{G}$ mutant homozygous of rs1063192 (GG vs. GA + AA) (OR: 0.25; 95\%CI: 0.06-1.00; $P=0.05)$ showed a threshold significance (Table 4).

\section{Discussion}

Studies on cardiovascular diseases in China (2016) reported that there were estimated 0.29 billion patients with cardiovascular disease (CVD) in China in 2015, of which CAD patients accounted for 11 million. CVD is considered the most important fatal disease and accounted for 42.61 and $45.01 \%$ of major causes of death among urban and rural Chinese residents in 2015, respectively. In other words, about two in every five deaths were attributed to CVD [1]. Traditional risk factors including smoking, obesity, low physical activity, hypertension, hyperlipidemia and DM are considered as the main factors responsible for onset and progression of coronary atherosclerosis [4]. In recent years, GWAS confirmed 
Table 1 The baseline clinical characteristics

\begin{tabular}{|c|c|c|c|}
\hline & MACCE group $(n=342)$ & Non-CAD group $(n=344)$ & $P$-value \\
\hline Age, year & $62.8 \pm 10.2$ & $50.5 \pm 11.5$ & $<0.0001$ \\
\hline Male, \% & $270(78.9)$ & $198(57.6)$ & $<0.0001$ \\
\hline $\mathrm{BMI}, \mathrm{kg} / \mathrm{m}^{2}$ & $25.7 \pm 3.2$ & $25.3 \pm 3.1$ & 0.147 \\
\hline Hypertension, \% & $241(70.5)$ & $44(12.8)$ & $<0.0001$ \\
\hline $\mathrm{DM}, \%$ & $134(39.2)$ & $14(4.1)$ & $<0.0001$ \\
\hline Hyperlipidemia, \% & $209(61.1)$ & $25(7.3)$ & $<0.0001$ \\
\hline Stroke, \% & $56(16.4)$ & $1(0.3)$ & $<0.0001$ \\
\hline PVD, \% & $31(9.1)$ & $0(0.0)$ & $<0.0001$ \\
\hline Smoking history, \% & $201(58.8)$ & $64(18.6)$ & $<0.0001$ \\
\hline $\mathrm{WBC},{ }^{*} 10^{9} / \mathrm{L}$ & $7.21 \pm 2.08$ & $6.25 \pm 1.73$ & $<0.0001$ \\
\hline Hemoglobin, $g / L$ & $136.7 \pm 14.9$ & $144.9 \pm 12.3$ & $<0.0001$ \\
\hline$A L T, I U / L$ & $30.2 \pm 22.6$ & $24.2 \pm 16.0$ & $<0.0001$ \\
\hline Serum creatinine, $\mu \mathrm{mol} / \mathrm{L}$ & $84.5 \pm 22.0$ & $72.6 \pm 18.4$ & $<0.0001$ \\
\hline Uric acid, $\mu \mathrm{mol} / \mathrm{L}$ & $322.1 \pm 88.3$ & $332.4 \pm 98.2$ & 0.151 \\
\hline Triglyceride, mmol/L & $1.77 \pm 0.94$ & $1.72 \pm 1.19$ & 0.533 \\
\hline Total cholesterol, mmol/L & $4.61 \pm 1.07$ & $4.68 \pm 1.15$ & 0.389 \\
\hline $\mathrm{HDL}-\mathrm{C}, \mathrm{mmol} / \mathrm{L}$ & $1.05 \pm 0.24$ & $1.15 \pm 0.32$ & $<0.0001$ \\
\hline LDL-C, mmol/L & $2.56 \pm 0.81$ & $2.87 \pm 0.88$ & $<0.0001$ \\
\hline $\mathrm{FPG}, \mathrm{mmol} / \mathrm{L}$ & $6.31 \pm 2.32$ & $5.61 \pm 1.23$ & $<0.0001$ \\
\hline CK-MB, IU/L & $19.4 \pm 40.9$ & $14.9 \pm 4.5$ & 0.046 \\
\hline $\mathrm{Hs}-\mathrm{CRP}, \mathrm{mg} / \mathrm{L}$ & $3.77 \pm 3.62$ & $2.23 \pm 1.57$ & $<0.0001$ \\
\hline
\end{tabular}

$A L T$ alanine transaminase, $B M I$, body mass index, $C A D$ coronary artery disease, $C K-M B$ creatine kinase-muscle/brain, $D M$ diabetes mellitus, $F P G$ fasting plasma glucose, HDL-C High-density lipoprotein cholesterol, $H s$-CRP High-sensitivity C-reactive protein, $L D L-C$ Low-density lipoprotein cholesterol, MACCE major adverse cardiovascular and cerebrovascular events, PVD peripheral vessel disease, WBC white blood cell count

that genetic factors also play an important role in occurrence and progression of CAD. It is of great significance to identify the predisposing genes of CAD to understand its pathogenesis, search for new therapeutic targets, establish individualized treatment and evaluate prognosis $[5-8,13]$.

The most important manifestation of coronary atherosclerosis progression is transformation of stable plaque into vulnerable plaque, leading to acute cardiac or cerebrovascular events. It was reported that cytobands of 9p21.3, 2q36.3, 6q25.1, 1q41, and 1p13.3 were all associated with adverse cardio-cerebrovascular events [14-16]. Therefore, six genes were selected as candidate genes, including CDKN2B-AS1, ADAMTS7, ABO, ADAMTS13, IL-18, PECAM1, in terms of references [8, 9, 19-24].

If mutant distributed significantly more in non-CAD group than MACCE group, it was considered as a probably protective factor. If mutant distributed significantly less in non-CAD group than MACCE group, it was considered as a probably risk factor. Under this principle, the results showed: on $C D K N 2 B-A S 1$ gene, G mutant of rs1063192, A mutant of rs1333042, and G mutant of rs9632884 may be protective mutants, while $G$ mutant of rs10757274, C mutant of rs1333049, and G mutant of rs4977574 may be risk mutants. In other words, the polymorphisms of CDKN2B-AS1 gene were possibly associated with progression or suppression of TVD.

The CDKN2B-AS1 gene, a gene cluster on 9p21.3, encodes a functional ribonucleic acid molecule, which causes epigenetic silencing on other genes. The mechanism how it involves in increased CAD onset risk remains unclear. A potential mechanism might be that expression of cell cycle inhibitor genes CDKN2A and $C D K N 2 B$ was decreased and smooth muscle cell proliferation regulated by transcription factors expressed from risk alleles was accelerated [8]. 9p21.3 was the first hereditary region identified, which was found closely associated with occurrence of $\mathrm{CAD}$, independent of traditional risk factors, such as hyperlipidemia, hypertension and DM $[8,10,11,24]$. It was reported that the risk alleles on 9p21.3 could indicate atherosclerotic plaque burden and predict severity of CAD [25]. Interestingly, our study also found that in recessive model, the MACCE risk in patients with G mutant homozygous of rs9632884 (GG vs. $\mathrm{GC}+\mathrm{CC}$ ) was about $1 / 4$ of whom with wild type homozygous or heterozygous. It indicated that $C D K N 2 B-A S 1$ gene on 9p21.3 not only related to onset risk and progression of atherosclerosis, but also suppression of coronary 
Table 2 Candidate SNP association analysis

\begin{tabular}{|c|c|c|c|c|c|}
\hline Gene & SNP & Allele model & MACCE group $(n=342)$ & $\begin{array}{l}\text { Non-CAD group } \\
(n=344)\end{array}$ & $P$-value \\
\hline \multirow[t]{21}{*}{ CDKN2B-AS1 } & \multirow[t]{3}{*}{$\mathrm{rs} 1063192 \mathrm{~A}>\mathrm{G}$} & $\mathrm{DO} A \mathrm{~A} / \mathrm{GG}+\mathrm{GA}$ & $223 / 119$ & $195 / 149$ & 0.022 \\
\hline & & $\mathrm{RE} \mathrm{GG} / \mathrm{GA}+\mathrm{AA}$ & $14 / 328$ & $15 / 329$ & 0.862 \\
\hline & & $\mathrm{CO}$ GG/GA/AA & $14 / 105 / 223$ & $15 / 134 / 195$ & 0.066 \\
\hline & \multirow[t]{3}{*}{ rs10757274 A > G } & $\mathrm{DO} A \mathrm{~A} / \mathrm{GG}+\mathrm{GA}$ & $74 / 268$ & $112 / 232$ & 0.001 \\
\hline & & $\mathrm{RE} \mathrm{GG} / \mathrm{GA}+\mathrm{AA}$ & $94 / 248$ & $65 / 279$ & 0.008 \\
\hline & & $\mathrm{CO}$ GG/GA/AA & $94 / 174 / 74$ & $65 / 167 / 112$ & 0.001 \\
\hline & \multirow[t]{3}{*}{ rs1333042 G > A } & $\mathrm{DO}$ GG/AA+GA & $177 / 165$ & $136 / 208$ & 0.001 \\
\hline & & $\mathrm{RE} A \mathrm{~A} / \mathrm{GA}+\mathrm{GG}$ & $23 / 319$ & $35 / 309$ & 0.104 \\
\hline & & $\mathrm{CO} A \mathrm{~A} / \mathrm{GA} / \mathrm{GG}$ & 23/142/177 & $35 / 173 / 136$ & 0.004 \\
\hline & \multirow[t]{3}{*}{ rs1333049 G > C } & $\mathrm{DO} \mathrm{GG} / \mathrm{CC}+\mathrm{GC}$ & $67 / 275$ & $105 / 239$ & 0.001 \\
\hline & & $\mathrm{RE} C \mathrm{C} / \mathrm{GC}+\mathrm{GG}$ & $101 / 241$ & $69 / 275$ & 0.004 \\
\hline & & $\mathrm{CO} C \mathrm{C} / \mathrm{GC} / \mathrm{GG}$ & $101 / 174 / 67$ & $69 / 170 / 105$ & 0.001 \\
\hline & \multirow[t]{3}{*}{ rs3217986 T>G } & $\mathrm{DO} T \mathrm{~T} / \mathrm{GG}+\mathrm{GT}$ & $279 / 63$ & $303 / 41$ & 0.018 \\
\hline & & $\mathrm{RE} \mathrm{GG} / \mathrm{GT}+\mathrm{TT}$ & $3 / 339$ & $0 / 344$ & 0.082 \\
\hline & & $\mathrm{CO}$ GG/GT/TT & $3 / 60 / 279$ & $0 / 41 / 303$ & 0.023 \\
\hline & \multirow[t]{3}{*}{ rs4977574 A > G } & $\mathrm{DO} A \mathrm{~A} / \mathrm{GG}+\mathrm{GA}$ & $73 / 269$ & $111 / 233$ & 0.001 \\
\hline & & $\mathrm{RE} \mathrm{GG} / \mathrm{GA}+\mathrm{AA}$ & $94 / 248$ & $65 / 279$ & 0.008 \\
\hline & & $\mathrm{CO}$ GG/GA/AA & $94 / 175 / 73$ & $65 / 168 / 111$ & 0.001 \\
\hline & \multirow[t]{3}{*}{ rs9632884 C > G } & $\mathrm{DO} C \mathrm{CC} / \mathrm{GG}+\mathrm{GC}$ & $192 / 150$ & 152/192 & 0.002 \\
\hline & & $\mathrm{RE} \mathrm{GG/GC}+\mathrm{CC}$ & $26 / 316$ & $25 / 319$ & 0.867 \\
\hline & & $\mathrm{CO}$ GG/GC/CC & 26/124/192 & $25 / 167 / 152$ & 0.004 \\
\hline \multirow[t]{3}{*}{ ADAMTS13 } & \multirow[t]{3}{*}{ rs1055432 C > A } & $\mathrm{DO} C \mathrm{C} / \mathrm{AA}+\mathrm{AC}$ & $242 / 99$ & $266 / 78$ & 0.057 \\
\hline & & $\mathrm{RE} A \mathrm{~A} / \mathrm{AC}+\mathrm{CC}$ & $4 / 337$ & $3 / 341$ & 0.695 \\
\hline & & CO AA/AC/CC & $4 / 95 / 242$ & $3 / 75 / 266$ & 0.164 \\
\hline \multirow[t]{3}{*}{ ABO } & \multirow[t]{3}{*}{ rs8176694 T > C } & $\mathrm{DO} T \mathrm{~T} / \mathrm{CC}+\mathrm{CT}$ & $315 / 25$ & $300 / 40$ & 0.050 \\
\hline & & $\mathrm{RE} C \mathrm{CC} / \mathrm{CT}+\mathrm{TT}$ & $6 / 334$ & $11 / 329$ & 0.219 \\
\hline & & $\mathrm{CO}$ CC/CT/TT & $6 / 19 / 315$ & $11 / 29 / 300$ & 0.141 \\
\hline
\end{tabular}

$C O$ codominant model, $D O$ dominant model, MACCE major adverse cardiovascular and cerebrovascular events, $R E$ recessive model, $S N P$ single nucleotide polymorphism

atherosclerosis worsening in TVD patients. Specific mechanism remains to be investigated.

Our study found that A mutant of rs1055432 on ADAMTS13 gene and C mutant of rs8176694 on $A B O$ gene showed a tendency of significant difference between the two groups. The ADAMTS13 gene encodes von Willebrand factor (vWF) cleaving protease, named ADAMTS13, closely related to acute thrombosis. vWF is a glycoprotein in serum, thrombocytic granule, or on endothelial cell surface, synthesized and secreted by vascular endothelial cells and megakaryocytes. vWF participates in platelet adhesion and aggregation in combination with platelet membrane glycoprotein $b$ and collagen at vascular lesions and stabilizes factor VIII activity by functioning as a carrier. Concentration of plasma ADAMTS13 decreases when vWF level increases during acute formation process of coronary thrombosis [20, 26, 27]. A possible speculation of potential mechanism might be that A mutant causes expression reduction of ADAMTS13, thus vWF concentration increases, which promoted platelet adhesion and aggregation. $A B O$ gene encodes $\mathrm{ABO}$ blood group antigens. An O-type blood-related variant might decrease the activity of glucosyl transferase, reduce concentration of vWF and factor VIII, and thus reduce risk of MI and venous thrombosis $[9,19]$. C mutant of rs8176694 lies on an intron. Whether it only acts as a mark or plays a role in regulation of gene expression worth further discussion.

Data on genetic background of TVD is limited. A 15year prospective study found that as well as age, increased body mass index, DM, low ejection fraction, left main artery stenosis, genetic variation in the interleukin6 promoter were an independent risk factor for the survival of patients with TVD, contributing to understanding its role in the progression of atherosclerosis. However, none of the remaining 21 investigated polymorphisms constituted significant independent risk 
Table 3 FDR BH adjustment

\begin{tabular}{lllll}
\hline Allele model & Gene & SNP & P-value & Q-value \\
\hline Dominant model & CDKN2B-AS1 & rs1333049 & 0.001 & 0.009 \\
& CDKN2B-AS1 & rs1333042 & 0.001 & 0.009 \\
& CDKN2B-AS1 & rs10757274 & 0.001 & 0.009 \\
& CDKN2B-AS1 & rs4977574 & 0.001 & 0.009 \\
& CDKN2B-AS1 & rs9632884 & 0.002 & 0.009 \\
Recessive model & CDKN2B-AS1 & rs3217986 & 0.018 & 0.054 \\
& CDKN2B-AS1 & rs1063192 & 0.022 & 0.0495 \\
& CDKN2B-AS1 & rs1333049 & 0.004 & 0.036 \\
& CDKN2B-AS1 & rs4977574 & 0.008 & 0.036 \\
& CDKN2B-AS1 & rs10757274 & 0.008 & 0.036 \\
Codominant model & CDKN2B-AS1 & rs1333049 & 0.001 & 0.009 \\
& CDKN2B-AS1 & rs4977574 & 0.001 & 0.009 \\
& CDKN2B-AS1 & rs10757274 & 0.001 & 0.009 \\
& CDKN2B-AS1 & rs9632884 & 0.004 & 0.018 \\
& CDKN2B-AS1 & rs1333042 & 0.004 & 0.018 \\
& CDKN2B-AS1 & rs3217986 & 0.023 & 0.069 \\
\hline
\end{tabular}

$F D R B H$ false discovery rate Benjamini-Hochberg

$Q$-value $=P$-value ${ }^{*}$ number of hypothesis testing/rank of $P$-value

Number of hypothesis testing $=$ number of SNPs detected on one gene factors of death in patients suffering from TVD, although the association with CAD has been previously reported [28]. Polymorphisms on ADAMTS7, IL-18, and PECAM1 showed no significant difference between the two groups in our study, also inconsistent with data reported in CAD population. Therefore, although TVD is considered as the advanced stage of development of CAD, the genetic characteristics of TVD patients may be some different from whole CAD population.

Atherosclerotic plaque formation is the fundamental pathophysiological mechanism of CAD. Whether acute coronary syndrome generates, due to plaque vulnerability, may be the key determinant factor of prognosis of CAD patients. With the deepening of research, concepts of blood vulnerability and patient vulnerability were raised. Pathophysiological mechanisms cover genetic mechanisms, multiple traditional risk factors, clotting cascade, and inflammation mechanisms. Our results might add something new to era of "blood vulnerability" and "patient vulnerability". As genetic factors are irreversible, population with genetic variants may be treated with more aggressive strategy including first and second prevention, in common view of multifactorial pathogenesis. It also makes sense of prognostic valuation. Models within genetic variants for risk stratification in order to expand "area under curve" worth further research in precision medicine era [29-31].

Table 4 Multivariate logistic regression

\begin{tabular}{|c|c|c|c|c|}
\hline Gene & SNP & Allele model & OR $(95 \% \mathrm{Cl})$ & $P$-value \\
\hline \multirow[t]{14}{*}{ CDKN2B-AS1 } & \multirow[t]{2}{*}{$\mathrm{rs} 1063192 \mathrm{~A}>\mathrm{G}$} & $\mathrm{DO} A \mathrm{~A} / \mathrm{GG}+\mathrm{GA}$ & $0.85(0.45,1.60)$ & 0.613 \\
\hline & & $\mathrm{RE} \mathrm{GG} / \mathrm{GA}+\mathrm{AA}$ & $0.25(0.06,1.00)$ & 0.05 \\
\hline & \multirow[t]{2}{*}{ rs10757274 A > G } & $\mathrm{DO} A \mathrm{AA} / \mathrm{GG}+\mathrm{GA}$ & $0.99(0.45,2.05)$ & 0.977 \\
\hline & & $\mathrm{RE} G \mathrm{G} / \mathrm{GA}+\mathrm{AA}$ & $0.86(0.42,1.74)$ & 0.67 \\
\hline & \multirow[t]{2}{*}{ rs1333042 G > A } & $\mathrm{DO} \mathrm{GG} / \mathrm{AA}+\mathrm{GA}$ & $1.00(0.53,1.86)$ & 0.99 \\
\hline & & $\mathrm{RE} A \mathrm{~A} / \mathrm{GA}+\mathrm{GG}$ & $2.14(0.79,5.83)$ & 0.137 \\
\hline & \multirow[t]{2}{*}{ rs1333049 G > C } & $\mathrm{DO} \mathrm{GG} / \mathrm{CC}+\mathrm{GC}$ & $1.43(0.69,2.98)$ & 0.338 \\
\hline & & $\mathrm{RE} C \mathrm{C} / \mathrm{GC}+\mathrm{GG}$ & $1.21(0.60,2.43)$ & 0.593 \\
\hline & \multirow[t]{2}{*}{ rs3217986 T>G } & $\mathrm{DO} T \mathrm{~T} / \mathrm{GG}+\mathrm{GT}$ & $1.29(0.53,3.14)$ & 0.572 \\
\hline & & $\mathrm{RE} \mathrm{GG} / \mathrm{GT}+\mathrm{TT}$ & & \\
\hline & \multirow[t]{2}{*}{ rs4977574 A > G } & $\mathrm{DO} A \mathrm{AA} / \mathrm{GG}+\mathrm{GA}$ & $1.00(0.48,2.06)$ & 0.989 \\
\hline & & $\mathrm{RE} G \mathrm{G} / \mathrm{GA}+\mathrm{AA}$ & $0.86(0.42,1.74)$ & 0.67 \\
\hline & \multirow[t]{2}{*}{ rs9632884 C > G } & $\mathrm{DO} C \mathrm{C} / \mathrm{GG}+\mathrm{GC}$ & $0.95(0.51,1.78)$ & 0.872 \\
\hline & & $\mathrm{RE} G \mathrm{G} / \mathrm{GC}+\mathrm{CC}$ & $0.24(0.09,0.65)$ & 0.005 \\
\hline \multirow[t]{2}{*}{ ADAMTS13 } & \multirow[t]{2}{*}{ rs1055432 C > A } & $\mathrm{DO} C \mathrm{C} / \mathrm{AA}+\mathrm{AC}$ & $1.43(0.72,2.86)$ & 0.307 \\
\hline & & $\mathrm{RE} A \mathrm{~A} / \mathrm{AC}+\mathrm{CC}$ & $1.34(0.03,64.99)$ & 0.882 \\
\hline \multirow[t]{2}{*}{$\mathrm{ABO}$} & \multirow[t]{2}{*}{ rs8176694 T>C } & $\mathrm{DO} T \mathrm{~T} / \mathrm{CC}+\mathrm{CT}$ & $0.28(0.07,1.14)$ & 0.075 \\
\hline & & $\mathrm{RE} C \mathrm{CC} / \mathrm{CT}+\mathrm{TT}$ & $0.70(0.09,5.53)$ & 0.733 \\
\hline
\end{tabular}

Cl confidence interval, OR odds ratio, SNP single nucleotide polymorphism 
Admittedly, the study has several limitations. Firstly, the relatively low number of control group reduced the power of the study. Secondly, it was considered as an "extreme population" study, in which it was much easier to find clues of genetic differences. Association found in case-control is weaker than prospective cohort study, which is being designed. Additionally, all patients were enrolled in single institution, mostly from the northern Han population, which limits the generalizability of our results. Nevertheless, this case-control study provides some new ideas on genetic factors which effect coronary atherosclerosis progression in Chinese TVD patients, in terms of both genetic and clinical data.

\section{Conclusion}

In patients with TVD in China, variant alleles on $C D K N 2 B-A S 1$ gene may form part of the genetic basis of coronary atherosclerosis progression, promoting or suppressing ischemic events.

\section{Abbreviations}

AMI: Acute myocardial infarction; CABG: Coronary artery bypass graft; CAD: Coronary artery disease; Cl: Confidence interval; CVD: Cardiovascular disease; DNA: Deoxyribonucleic acid; FDR: False discovery rate; GWAS: Genome wide association study; MACCE: Major adverse cardiac and cerebrovascular event; MAF: Minor allele frequency; ODT: Optimizing drug therapy; OR: Odds ratio; PCl: Percutaneous coronary intervention; PCR: Fluorescence polymerase chain reaction; RNA: Ribonucleic acid; SNP: Single nucleotide polymorphism; TVD: Three-vessel disease; VWF: von Willebrand factor

\section{Acknowledgements}

We thank all patients for participating in this study. We are also grateful to the Center for Genetics \& Genomic Analysis, and Genesky Biotechnologies Inc. (Shanghai, 201203) for their technical support in sequencing.

\section{Authors' contributions \\ $\mathrm{RL}$ contributed to all aspects of this study, including study concept and design, data acquisition, analysis, and interpretation, and drafting and revising the report. $L S$ and JQY contributed to revising the report. $L$, $L X$, JJX, and XYZ contributed to data acquisition. ZG and XFT contributed to statistical analysis. JQY and RLG worked with RL and contributed to initial study conception and design, data interpretation, and critical revision of the report. All authors have approved the final article.}

\section{Funding}

This work is supported by the National Natural Science Foundation of China (Grants no. 81770365) and the National Key Research and Development Program of China during the 13th Five-Year Plan Period (Project no. 2016YFC1301301). The funding bodies mainly supported blood sample collection, DNA library building and SNP genotyping.

\section{Availability of data and materials}

The variant alleles were deposited into ClinVar database of NCBI/NLM/NIH. The accession numbers for this submission are SCV001161727 -

sCv001161760.

\section{Ethics approval and consent to participate}

Ethical approvals were obtained from the Fuwai Hospital Research Ethics Committees. The Institutional Review Board approved the study protocol and all patients signed written informed consent before providing blood samples and invasive treatment, including full set of risk-informed consent and information use consent for scientific purposes.
Consent for publication

Not applicable.

\section{Competing interests}

The authors declare that they have no competing interests.

Received: 25 February 2019 Accepted: 26 March 2020

Published online: 15 April 2020

\section{References}

1. Organization W H. WHO global status report on noncommunicable diseases 2010. Women. 2011:47(26):2562-3.

2. Wang $Y$, Zhu HJ, Zeng $Y$. Advances in genomics studies for coronary artery disease. Zhongguo Yi Xue Ke Xue Yuan Xue Bao. 2017;37(4):475-81.

3. Writing group of report on cardiovascular disease in China. Report on Cardiovascular Disease in China (2016): Abstract. Chin Circul J. 2017;32(6): $521-30$

4. Ge J, Xu Y. Internal Medicine. 8th ed. Beijing: People's Medical Publishing House; 2014.

5. Prins BP, Lagou V, Asselbergs FW, Snieder H, Fu J. Genetics of coronary artery disease: genome-wide association studies and beyond. Atherosclerosis. 2012;225:1-10.

6. CARDIoGRAMplusC4D Consortium. Large-scale association analysis identifies new risk loci for coronary artery disease. Nat Genet. 2013;45:25-33.

7. Lu X, Wang L, Chen S, Lin H, Yang X, Shi Y, Cheng J, Liang Z, Charles Gu C, Huang J, Wu T, Ma Y, Li J, Cao J, Chen J, Ge D, Fan Z, Li Y, Zhao L, Li H, Zhou X, Chen L, Liu D, Chen J, Duan X, Hao Y, Wang L, Lu F, Liu Z, Yao C, Shen C, Xiaodong P, Yu L, Fang X, Xu L, Jianjun M, Wu X, Zheng R, Wu N, Zhao Q, Li Y, Liu X, Wang M, Yu D, Hu D, Xu J, Guo D, Sun D, Wang Q, Yang Y, Liu F, Mao Q, Liang X, Ji J, Chen P, Mo X, Li D, Chai G, Tang Y, Li X, Zhenhan D, Liu X, Dou C, Yang Z, Meng Q, Dong W, Wang R, Yang J, Schunkert H, Samani NJ, Kathiresan S, Reilly MP, Erdmann J, The Coronary ARtery Dlsease Genome-Wide Replication And Meta-Analysis (CARDloGRAM) Consortium, Peng X, Wu X, Liu D, Yang Y, Chen R, Qiang B, Gu D. Genomewide association study in Han Chinese identifies four new susceptibility loci for coronary artery disease. Nat Genet. 2012;44(8):890.

8. McPherson R, Pertsemlidis A, Kavaslar N, Stewart A, Roberts R, Cox DR, Hinds D, Pennachio L, Tybjaerg-Hansen A, Folsom AR, Boerwinkle E, Hobbs $\mathrm{HH}$, Cohen JC. A common allele on chromosome 9 associated with coronary heart disease. Science. 2007;316(5830):1488.

9. Reilly MP, Li M, He J, Ferguson JF, Stylianou IM, Mehta NN, Burnett MS, Devaney JM, Knouff CW, Thompson JR, Horne BD, Stewart AF, Assimes TL, Wild PS, Allayee H, Nitschke PL, Patel RS, Consortium MIG, Consortium WTCC, Martinelli N, Girelli D, Quyyumi AA, Anderson JL, Erdmann J, Hall AS, Schunkert H, Quertermous T, Blankenberg S, Hazen SL, Roberts R, Kathiresan S, Samani NJ, Epstein SE, Rader DJ. Identification of ADAMTS7 as a novel locus for coronary atherosclerosis and association of $\mathrm{ABO}$ with myocardial infarction in the presence of coronary atherosclerosis: two genome-wide association studies. Lancet. 2011;377(9763):383-92.

10. WTCCC. Genome-wide association study of 14,000 cases of seven common diseases and 3,000 shared controls. Nature. 2007:447:661-78.

11. Roberts R. Genetics of coronary artery disease: an update. Methodist Debakey Cardiovasc J. 2014;10(1):7-12.

12. Dandona S, Chen L, Fan M, Alam MA, Assogba O, Belanger M, Williams K, Wells GA, Tang WH, Ellis SG, Hazen SL, McPherson R, Roberts R, Stewart AF. The transcription factor GATA-2 does not associate with angiographic coronary artery disease in the Ottawa heart genomics and Cleveland Clinic GeneBank studies. Hum Genet. 2010;127:101-5.

13. Wang F, Xu CQ, He Q, Cai JP, Li XC, Wang D, Xiong X, Liao YH, Zeng QT, Yang YZ, Cheng X, Li C, Yang R, Wang CC, Wu G, Lu QL, Bai Y, Huang YF, Yin D, Yang Q, Wang XJ, Dai DP, Zhang RF, Wan J, Ren JH, Li SS, Zhao YY, Fu FF, Huang Y, Li QX, Shi SW, Lin N, Pan ZW, Li Y, Yu B, Wu YX, Ke YH, Lei J, Wang N, Luo CY, Ji LY, Gao LJ, Li L, Liu H, Huang EW, Cui J, Jia N, Ren X, Li $H$, Ke T, Zhang XQ, Liu JY, Liu MG, Xia H, Yang B, Shi LS, Xia YL, Tu X, Wang QK. Genome-wide association identifies a susceptibility locus for coronary artery disease in the Chinese Han population. Nat Genet. 2011;43(4):345-9.

14. Anna S, Witold P, Ewa W, Dominika M, Malgorzata S, Anna NJ, Robert M, Slawomir D, Wlodzimierz JM, Karol AK. Polymorphism of 9p21.3 locus is associated with 5-year survival in high-risk patients with myocardial infarction. Plos one. 2014;9(8):e72333. 
15. Hara M, Sakata Y, Nakatani D, Suna S, Usami M, Matsumoto S, Ozaki K, Nishino M, Sato H, Kitamura T, Nanto S, Hamasaki T, Tanaka T, Hori M, Komuro I. Reduced risk of recurrent myocardial infarction in homozygous carriers of the chromosome 9p21 rs1333049 C risk allele in the contemporary percutaneous coronary intervention era: a prospective observational study. BMJ Open. 2014;4:e005438.

16. Lee IT, Goodarzi MO, Lee WJ, Rotter Jl, Chen Yl, Liang KW, Lee WL, Sheu $\mathrm{WH}$. The chromosome 9p21 variant not predicting long-term cardiovascular mortality in Chinese with established coronary artery disease: an eleven-year follow-up study. Biomed Res Int. 2014;2014(1):626907.

17. ZHANG C, Dong WA, HOU BJ, JIANG L, $\sqcup X U$, Jian TI, YY ZHAO, XY ZHAO, $X X$ FENG, Zhang Y, Kai SU. Prognostic values of serum chloride and sodium levels in patients with three-vessel disease. Biomed Environ Sci. 2019;32(4): 250-9.

18. Chi S, Song JH, Tan MS, Zhang W, Wang ZX, Jiang T, Tan L, Yu JT. Association of single-nucleotide polymorphism in ank1 with late-onset Alzheimer's disease in Han Chinese. Mol Neurobiol. 2016;53(9):6476-81.

19. He M, Wolpin B, Rexrode K, Manson JE, Rimm E, Hu FB, Qi L. ABO blood group and risk of coronary heart disease in two prospective cohort studies. Arterioscler Thromb Vasc Bio. 2012;32(9):2314-20.

20. Matsukawa M, Kaikita K, Soejima K, Fuchigami S, Nakamura Y, Honda T, Tsujita K, Nagayoshi Y, Kojima S, Shimomura H, Sugiyama S, Fujimoto K, Yoshimura M, Nakagaki T, Ogawa H. Serial changes in von Willebrand factor-cleaving protease (ADAMTS13) and prognosis after acute myocardial infarction. Am J Cardiol. 2007;100(5):758-63.

21. Blankenberg S, Tiret L, Bickel C, Peetz D, Cambien F, Meyer J, Rupprecht HJ, Investigators AG. Interleukin-18 is a strong predictor of cardiovascular death in stable and unstable angina. Circulation. 2002;106(1):24-30.

22. Song FC, Chen AH, Tang XM, Zhang WX, Qian XX, Li JQ, Lu Q. Association of platelet endothelial cell adhesion molecule-1 gene polymorphism with coronary heart disease. Acad J First Med Coll PLA. 2003;23(2):156.

23. Garcia C, Julier K, Bestmann L, Zollinger A, von Segesser LK, Pasch T, Spahn DR, Zaugg M. Preconditioning with sevoflurane decreases PECAM-1 expression and improves one-year cardiovascular outcome in coronary artery bypass graft surgery. Br J Anaesth. 2005;94(2):159-65.

24. Samani NJ, Erdmann J, Hall AS, Hengstenberg C, Mangino M, Mayer B, Dixon RJ, Meitinger T, Braund P, Wichmann HE, Barrett JH, König IR, Stevens SE, Szymczak S, Tregouet DA, lles MM, Pahlke F, Pollard H, Lieb W, Cambien F, Fischer M, Ouwehand W, Blankenberg S, Balmforth AJ, Baessler A, Ball SG, Strom TM, Braenne I, Gieger C, Deloukas P, Tobin MD, Ziegler A, Thompson JR, Schunkert H, WTCCC and the Cardiogenics Consortium. Genome wide association analysis of coronary artery disease. N Engl J Med. 2007;357:44353.

25. Patel RS, Su S, Neeland IJ, Ahuja A, Veledar E, Zhao J, Helgadottir A, Holm H, Gulcher JR, Stefansson K, Waddy S, Vaccarino V, Zafari AM, Quyyumi AA. The chromosome 9p21 risk locus is associated with angiographic severity and progression of coronary artery disease. Eur Heart J. 2010;31:3017-23.

26. Kaikita K, Soejima K, Matsukawa M, Nakagaki T, Ogawa H. Reduced von Willebrand factor-cleaving protease (ADAMTS13) activity in acute myocardial infarction. J Thrombosis Haemostasis. 2006;4(11):2490-3.

27. Morici N, Cantoni S, Panzeri F, Sacco A, Rusconi C, Stucchi M, Oliva F, von Cattaneo M. Willebrand factor and its cleaving protease ADAMTS13 balance in coronary artery vessels: Lessons learned from thrombotic thrombocytopenic purpura. A narrative review. Thromb Res. 2017;155. https://doi.org/10.1016/j.thromres.2017.05.011.

28. Máchal J, Pávková-Goldbergová M, Hlinomaz O, Groch L, Vašků A. Patients with chronic three-vessel disease in a 15-year follow-up study: genetic and non-genetic predictors of survival. Medicine (Baltimore). 2014;93(28):e278.

29. Rosendorff C, Lackland DT, Allison M, Aronow WS, Black HR, Blumenthal RS, Cannon CP, de Lemos JA, Elliott WJ, Findeiss L, Gersh BJ, Gore JM, Levy D, Long JB, O'Connor CM, O'Gara PT, Ogedegbe G, Oparil S, White WB, American Heart Association, American College of Cardiology, and American Society of Hypertension. Treatment of hypertension in patients with coronary artery disease: a scientific statement from the American Heart Association, American College of Cardiology, and American Society of Hypertension. Circulation. 2015;131(19):e435-70.

30. Páramo JA, Rodríguez JA, Orbe J. Vulnerable plaque versus vulnerable patient: emerging blood biomarkers for risk stratification. Endocr Metab Immune Disord Drug Targets. 2007;7(3):195-201.
31. Raggi P, Pontone G, Andreini D. Role of new imaging modalities in pursuit of the vulnerable plaque and the vulnerable patient. Int J Cardiol. 2018;250: 278-83.

\section{Publisher's Note}

Springer Nature remains neutral with regard to jurisdictional claims in published maps and institutional affiliations.
Ready to submit your research? Choose BMC and benefit from:

- fast, convenient online submission

- thorough peer review by experienced researchers in your field

- rapid publication on acceptance

- support for research data, including large and complex data types

- gold Open Access which fosters wider collaboration and increased citations

- maximum visibility for your research: over $100 \mathrm{M}$ website views per year

At BMC, research is always in progress.

Learn more biomedcentral.com/submissions 